\title{
Regulation of Alkaline Phosphatase Synthesis in Candida utilis
}

\author{
By NiEves GARCíA AlVAREZ, M. PAZ SUÁREZ RENDUELES,* \\ PILAR FERNÁNDEZ AND SANTIAGO GASCÓN \\ Departamento Interfacultativo de Bioquímica, Facultades de Ciencias y Medicina, \\ Universidad de Oviedo, Oviedo, Spain
}

(Received 3 August 1981; revised 13 October 1981)

Synthesis of alkaline phosphatase in Candida utilis, unlike that of the two molecular forms of acid phosphatase, is not controlled by inorganic phosphate in the culture medium. The nature of the carbon source seems to play an important role in the regulation of this enzyme. Growth on a fermentable carbon source such as glucose, fructose or mannose leads to a constitutive synthesis of the enzyme which stops as soon as the sugar is exhausted, even though the yeast continues to grow on the products of the sugar fermentation. On transfer of cells from a glucose-containing to an ethanol-containing medium alkaline phosphatase synthesis stops immediately, whereas synthesis of the enzyme starts immediately on transfer of cells from an ethanol-containing to a glucose-containing medium. Transfer to growth on a different carbon source has no effect on the synthesis of the two forms of acid phosphatase. Thus, it seems that synthesis of acid and alkaline phosphatase in Candida utilis is regulated by completely different mechanisms.

\section{INTRODUCTION}

The mechanisms that regulate synthesis of the non-specific phosphomonoesterase, alkaline phosphatase (EC 3.1.3.1), in yeasts are far from clear. Inorganic phosphate appears to affect enzyme synthesis differently in different strains. Thus, in some strains of Saccharomyces cerevisiae (Schurr \& Yagil, 1971; Onishi et al., 1979) and Saccharomyces carlsbergensis (Tonino \& Steyn-Parvé, 1963) alkaline phosphatase is derepressed by phosphate starvation, while in Schizosaccharomyces pombe (Mitchison \& Creanor, 1969) and in a mutant strain of Saccharomyces cerevisiae (Elorza et al., 1978) the enzyme seems to be constitutive.

Genetic analysis (Toh-e et al., 1975) indicates that in Saccharomyces cerevisiae the repressible alkaline phosphatase structural gene is different from those coding for the constitutive and repressible acid phosphatases (Toh-e et al., 1973, 1975). However, some of the products of the regulatory genes involved in the synthesis of the repressible acid phosphatase are also necessary for the complete derepression of the alkaline phosphatase. In addition, a second, constitutively synthesized, alkaline phosphatase has been reported in Saccharomyces cerevisiae (Toh-e et al., 1976).

The enzyme system has been thoroughly studied in Neurospora crassa, where the structural genes coding for the repressible alkaline and acid phosphatases, although different, are under the control of the same three regulatory genes, $n u c-1^{+}$, preg $^{+}$, and nuc- $2^{+}$ (Lehman \& Metzenberg, 1976; Nelson et al., 1976). A model based on genetic results has been developed (Littlewood et al., 1975; Metzenberg \& Chia, 1979) for the control of the synthesis of both enzymes, in which inorganic phosphate, or a co-repressor derived from it, is of a great importance. 
Candida utilis has two forms of acid phosphatase (Fernández et al., 1981a) which are derepressed under conditions of phosphate starvation (Fernández et al., 1982), but no constitutive acid phosphatase has been found. This organism also has a non-specific alkaline phosphatase which is located inside the cell, mainly in the vacuole (Fernández et al., 1981 b). In the present paper we show that inorganic phosphate plays no role in the regulation of alkaline phosphatase in Candida utilis, whereas the nature of the carbon source appears to have an important role in this regulation.

\section{METHODS}

Yeast strain and growth conditions. Candida utilis strain C.E.C.T. no. 1061 was from the Spanish Collection of Yeast Cultures (C.E.C.T., Department of Microbiology, University of Salamanca, Spain). This organism can utilize glucose, sucrose and one-third of the raffinose molecule (it synthesizes invertase but not $\alpha$-galactosidase), but not maltose, melibiose and galactose.

Cells were grown in a chemically defined medium (Kitazume et al., 1962) which contained various carbon sources $(2 \%, \mathrm{w} / \mathrm{v})$ as required. The medium was supplemented with $\mathrm{KH}_{2} \mathrm{PO}_{4}$, as a source of inorganic phosphate, at the concentrations indicated in each experiment. Cultures were incubated at $28{ }^{\circ} \mathrm{C}$ with shaking in a Gallenkamp orbital incubator and growth was followed by measuring the absorbance at $600 \mathrm{~nm}$.

Chemicals. D-Glucose, D-fructose, D-mannose and $\mathrm{KH}_{2} \mathrm{PO}_{4}$ were from Merck. $p$-Nitrophenyl phosphate, $p$-nitrophenol, glucose oxidase, peroxidase and $o$-dianisidine were from Sigma. All the other chemicals used were obtained from commercial sources and were of the highest purity available.

Preparation of cell-free extracts. Samples $(10 \mathrm{ml})$ were removed from cultures at different times of growth and cells were collected by centrifugation at $4000 \mathrm{~g}$ for $10 \mathrm{~min}$, washed once with distilled water and then resuspended in $0.05 \mathrm{M}$-Tris $/ \mathrm{HCl}$ buffer $\mathrm{pH}$ 7.5. Cells were broken in a Braun MSK homogenizer with glass beads $(0.45-0.50 \mu \mathrm{m}$ diam.) for $2 \mathrm{~min}$. This treatment disrupted $100 \%$ of the cells as judged by light microscopy. The glass beads were removed by passing the homogenate through a coarse sintered-glass filter. The extracts were centrifuged at $10000 \mathrm{~g}$ in a Beckman microcentrifuge for $15 \mathrm{~min}$ and the supernatants were used for enzyme determinations.

Enzyme Assays. Acid phosphatase was assayed in intact cells by measuring the liberation of $p$-nitrophenol from $p$-nitrophenyl phosphate as described previously (Fernández et al., 1981a). When the reaction was carried out in $0.1 \mathrm{M}$-acetate buffer $\mathrm{pH} 4.5$, the total acid phosphatase activity (corresponding to the two molecular forms of the enzyme) was measured. When the assay was performed in $0.1 \mathrm{M}$-Tris/ $\mathrm{HCl}$ buffer $\mathrm{pH} 7.5$, only the activity due to the 'light' molecular form was detected. Under these assay conditions alkaline phosphatase activity is not detected as the enzyme is located intracellularly.

Alkaline phosphatase activity was determined in cell-free extracts by measuring the liberation of $p$-nitrophenol from $p$-nitrophenyl phosphate in $0.1 \mathrm{M}$-glycine/ $\mathrm{NaOH}$ buffer $\mathrm{pH} 9.0$ containing $20 \mathrm{mM}-\mathrm{Mg}^{2+}$. Under these assay conditions only the activity of alkaline phosphatase was detected, because both forms of acid phosphatase are inactive at $\mathrm{pH} 9 \cdot 0$.

One unit $(\mathrm{U})$ of acid or alkaline phosphatase is defined as the amount of enzyme which catalyses the liberation of $1 \mu \mathrm{mol} p$-nitrophenol in $1 \mathrm{~min}$ from the substrate under the assay conditions described above.

Determination of sugars. The disappearance of glucose from the medium was followed using the second step of the invertase assay, as described previously (Gascón \& Lampen, 1968). Fructose and mannose were measured by their reducing power according to Somogyi (1952) as described by Ashwell (1957).

Phosphate determination. Phosphate in the culture medium was determined by the method of Ames (1966).

\section{RESULTS}

\section{Influence of extracellular phosphate on alkaline phosphatase levels}

The effect of different concentrations of extracellular inorganic phosphate on alkaline phosphatase levels in $C$. utilis is shown in Fig. 1. As reported previously (Fernández et al., $1982)$, the growth yields were similar in both low-phosphate $(0.6 \mathrm{~mm})$ and high-phosphate $(20 \mathrm{~mm})$ media, although there was a slight enhancement of the growth rate after glucose exhaustion in the high-phosphate medium. The levels of alkaline phosphatase were similar in both the low- and high-phosphate media, whereas the total acid phosphatase showed derepression of enzyme synthesis upon phosphate starvation (Fig. 1a) and complete repression in the high-phosphate medium (Fig. $1 b$ ). 


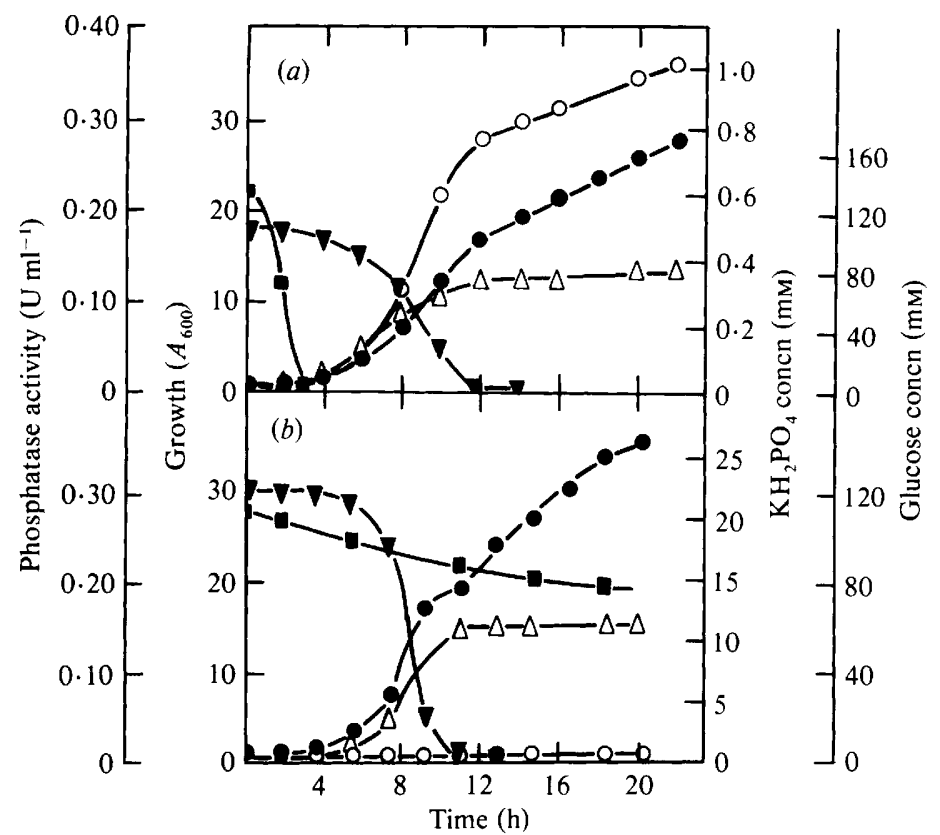

Fig. 1. Effect of extracellular inorganic phosphate on acid and alkaline phosphatase levels. Cells were grown in a chemically defined medium with $2 \%(\mathrm{w} / \mathrm{v})$ glucose as the carbon source and $\mathrm{KH}_{2} \mathrm{PO}_{4}$ at $0.6 \mathrm{~mm}(a)$ or $20 \mathrm{~mm}(b)$. Cell growth, measured as $A_{600}(O)$; total acid phosphatase activity, determined at $\mathrm{pH} 4.5$ in intact cells $(\mathrm{O})$; alkaline phosphatase activity, determined at $\mathrm{pH} 9.0$ in cell-free extracts $(\triangle)$; inorganic phosphate concentration $(\mathbf{\square})$; glucose concentration $(\boldsymbol{\nabla})$.

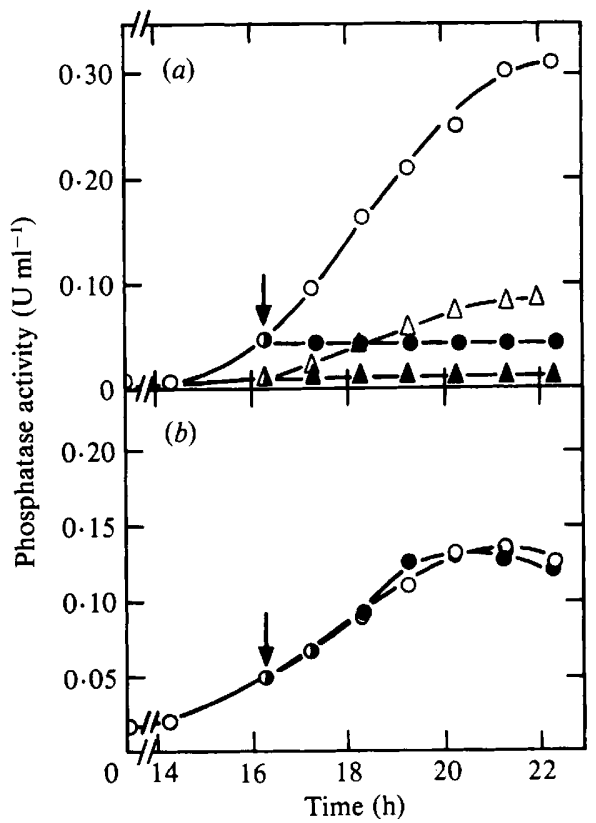

Fig. 2. Effect of inorganic phosphate addition on acid and alkaline phosphatase levels. Cells were grown in a chemically defined medium with $2 \%(\mathrm{w} / \mathrm{v})$ glucose and $0.6 \mathrm{mM}-\mathrm{KH}_{2} \mathrm{PO}_{4}$. At the time indicated by the arrow, when no phosphate remained in the culture medium, the culture was divided into two portions; one served as the control (open symbols) and the other was supplemented with $20 \mathrm{mM}-\mathrm{KH}_{2} \mathrm{PO}_{4}$ (closed symbols). (a) Total acid phosphatase activity, measured at pH 4.5 in intact cells $(\mathrm{O}, \mathrm{O})$; 'light' acid phosphatase activity, measured at $\mathrm{pH} 7.5$ in intact cells $(\triangle, \Delta)$. (b) Alkaline phosphatase activity, measured at pH 9.0 in cell-free extracts $(O, O)$. 


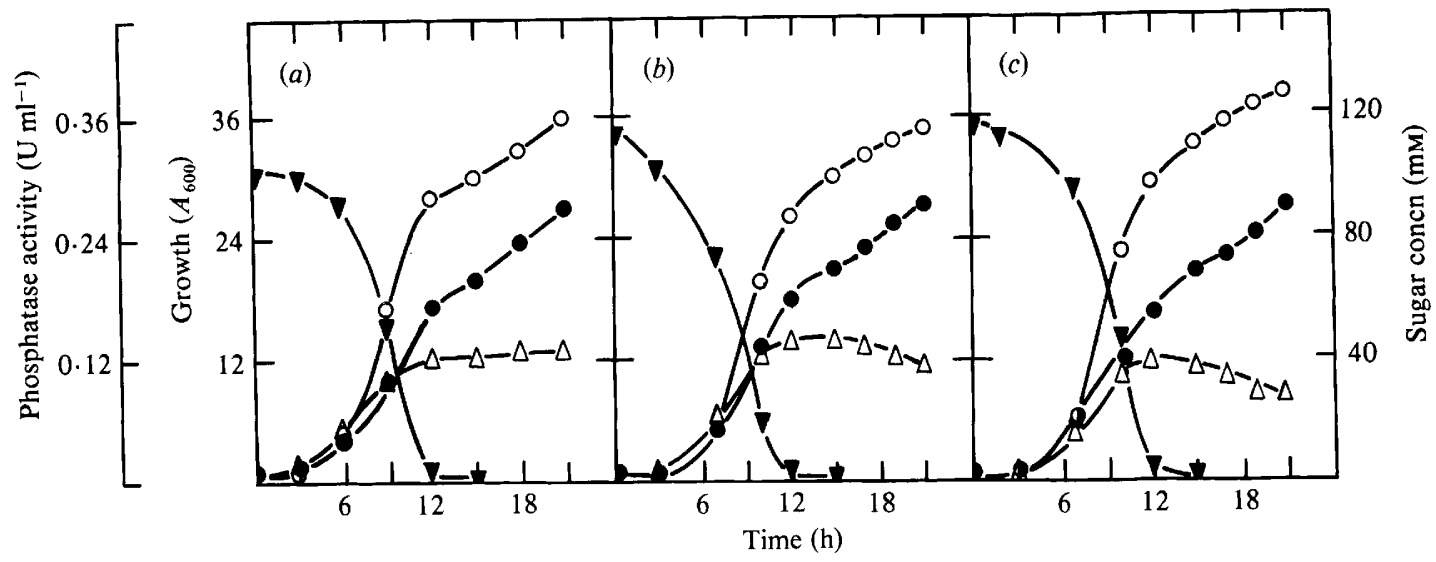

Fig. 3. Acid and alkaline phosphatase activities in chemically defined media containing glucose $(a)$, fructose (b) or mannose (c) (each at $2 \%, \mathrm{w} / \mathrm{v}$ ) and $\mathrm{KH}_{2} \mathrm{PO}_{4}(0.6 \mathrm{mM})$. Cell growth, measured as $A_{600}$ (O); total acid phosphatase activity, determined at $\mathrm{pH} 4.5$ in intact cells $(\mathrm{O})$; alkaline phosphatase activity, determined at $\mathrm{pH} 9.0$ in cell-free extracts $(\triangle)$; sugar concentration $(\boldsymbol{\nabla})$.

We also investigated the effect on acid and alkaline phosphatase levels of adding inorganic phosphate to phosphate-starved cultures. Cells were grown in a chemically defined medium supplemented with $0.6 \mathrm{~mm}$-phosphate. Once the phosphate had been exhausted from the medium, the culture was divided into two portions; one served as the control and the other was supplemented with $20 \mathrm{mM}$-phosphate, The addition of inorganic phosphate caused a slight increase in the rate of glucose consumption. Acid and alkaline phosphatase activities in each culture are shown in Fig. 2. There was no further increase in either 'heavy' or 'light' acid phosphatase activity following the phosphate addition (Fig. $2 a$ ), whereas the increase in alkaline phosphatase activity was unaffected (Fig. $2 b$ ).

\section{Effect of different carbon sources on alkaline phosphatase activity in chemically defined medium}

Candida utilis was grown with glucose (Fig. $3 a$ ), fructose (Fig. $3 b$ ) or mannose (Fig. $3 c$ ) as the sole carbon source, together with $0.6 \mathrm{~mm}$-phosphate. This concentration of phosphate was chosen because it allowed us to study acid phosphatase synthesis in the same cultures. In all three cases, the total acid phosphatase activity increased in parallel with cell growth once the phosphate was exhausted from the medium, irrespective of whether the cells were utilizing the sugars or the products of their fermentation. This was not the case with alkaline phosphatase activity which followed growth while the cells were utilizing the sugars as carbon sources, but showed no further increase once the sugars were exhausted from the medium, although growth continued.

With ethanol as the sole carbon source, growth of $C$. utilis was markedly slower than in the cultures with a fermentable carbon source, and the inorganic phosphate disappeared from the medium only after $7 \mathrm{~h}$ of growth (Fig. 4). Acid phosphatase activity was detected once the phosphate was exhausted and subsequently increased in parallel with growth, but there was little alkaline phosphatase activity under these conditions.

\section{Alkaline phosphatase activity in cells transferred from medium containing one carbon source to another}

Cells were grown for $8 \mathrm{~h}$ in media containing glucose or ethanol and then transferred, with aseptic precautions, into prewarmed $\left(28^{\circ} \mathrm{C}\right)$ media containing ethanol or glucose, respectively. Growth of the cells following transfer from glucose- to ethanol-containing medium started after a lag of $1 \mathrm{~h}$ and continued at a slower rate than in the 


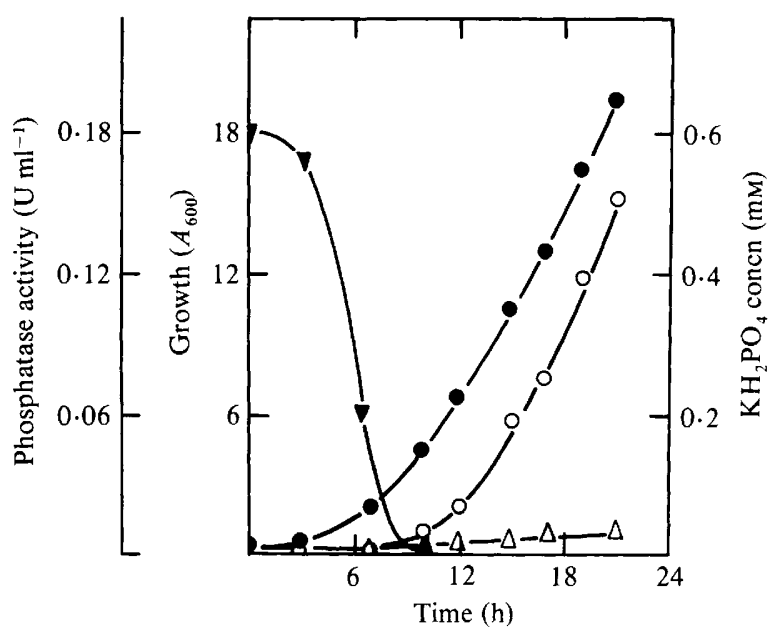

Fig. 4. Acid and alkaline phosphatase activities in chemically defined medium containing ethanol $(2 \%$, w/v) and $\mathrm{KH}_{2} \mathrm{PO}_{4}(0.6 \mathrm{~mm})$. Cell growth, measured as $A_{600}(O)$; total acid phosphatase activity, determined at $\mathrm{pH} 4.5$ in intact cells $(\mathrm{O})$; alkaline phosphatase activity, determined at $\mathrm{pH} 9.0$ in cell-free extracts $(\triangle)$; phosphate concentration $(\boldsymbol{\nabla})$.

glucose-containing medium. Transfer of cells from ethanol- to glucose-containing medium caused an enhancement of cell growth which started almost immediately after the transfer (Fig. 5). The increase in alkaline phosphatase activity was completely abolished by transfer of cells from glucose- to ethanol-containing medium but was markedly stimulated following transfer of cells from ethanol- to glucose-containing medium (Fig. 6a). Acid phosphatase showed completely different behaviour (Fig. $6 b$ ). Transfer of cells from a medium containing one carbon source to another carbon source did not affect the enzyme activity, which increased in parallel with cell growth in all cases once the inorganic phosphate had been exhausted from the medium.

\section{DISCUSSION}

The concentration of an intracellular protein is the result of a balanced interplay between its synthesis and degradation. Regulation of a protein level can thus be achieved by an alteration either in its rate of biosynthesis or in its rate of degradation. Although below we discuss changes in alkaline phosphatase levels as being the immediate result of changes in its biosynthesis, we cannot rule out alternative mechanisms such as inactivation or activation, though these seem unlikely on the basis of the results obtained.

Our results demonstrate that alkaline phosphatase levels in $C$. utilis are not controlled by phosphate. The amount of enzyme is not related to the extracellular concentration of inorganic phosphate, and addition of inorganic phosphate to actively synthesizing cells changes neither the rate of synthesis nor the level of enzyme reached.

Previous results from our laboratory (Fernández et al., 1981a) have shown that in the yeast strain under study there are two molecular forms of acid phosphatase, which are clearly differentiated by their $\mathrm{pH}$-activity profiles and separable by gel filtration on Sephadex G-200. The onset of the synthesis of both enzymes occurs when inorganic phosphate is exhausted from the medium (Fernández et al., 1982). We have shown here that addition of inorganic phosphate to actively synthesizing cells causes a total inhibition of the synthesis of both molecular forms of acid phosphatase. Thus, in C. utilis, extracellular inorganic phosphate plays an important role in the regulation of acid phosphatase but not alkaline phosphatase synthesis. 


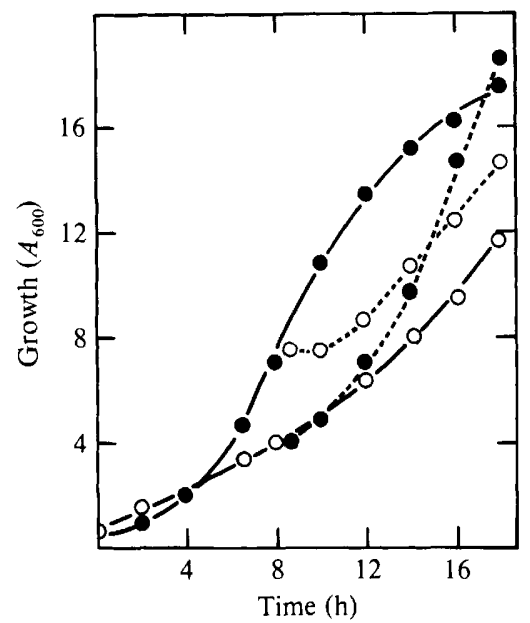

Fig. 5. Effect on growth of transfer from media containing glucose or ethanol (each at $2 \%$, w/v) to media containing ethanol or glucose (each at $2 \%$, w/v), respectively. Glucose-pregrown cells transferred to glucose $\left(\mathrm{O}_{-}\right)$and ethanol $\left(\mathrm{O}_{--} \mathrm{O}\right)$; ethanol-pregrown cells transferred to glucose $\left(\mathrm{O}_{-}\right)$and ethanol $(\mathrm{O}-\mathrm{O})$.
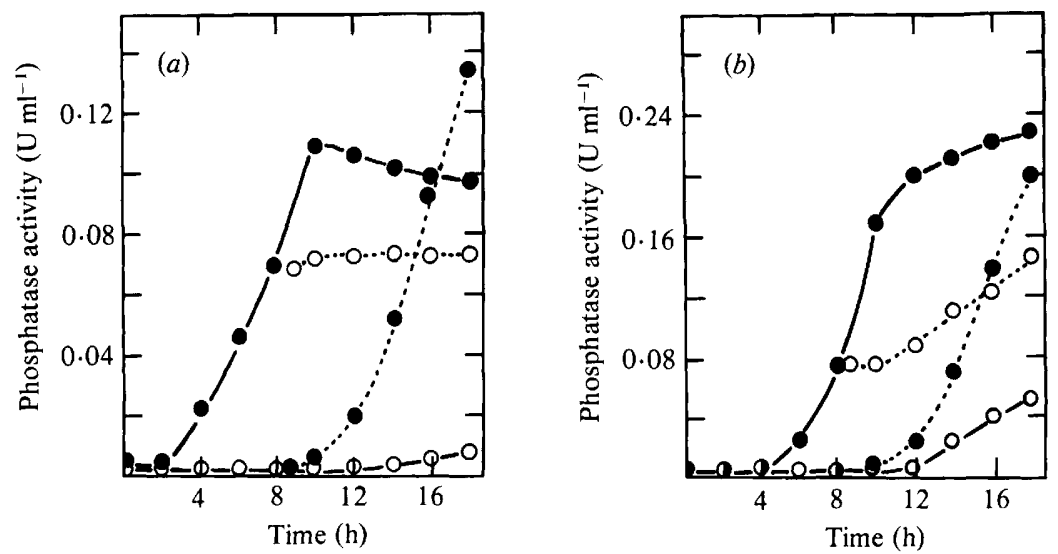

Fig. 6. Effect on alkaline phosphatase $(a)$ and acid phosphatase $(b)$ activities of transfer from media containing glucose or ethanol (each at $2 \%, \mathrm{w} / \mathrm{v}$ ) to media containing ethanol or glucose (each at $2 \%$, $\mathrm{w} / \mathrm{v}$ ), respectively. Samples are those corresponding to the cultures represented in Fig. 5. Glucose-pregrown cells transferred to glucose (-O) and ethanol $\left(\mathrm{O}_{-}-\mathrm{O}\right)$; ethanol-pregrown cells transferred to glucose

) and ethanol $(\mathrm{O}-\mathrm{O})$.

Similar behaviour has been reported in a thermosensitive mutant of Saccharomyces cerevisiae (Elorza et al., 1978) and in Schizosaccharomyces pombe (Mitchison \& Creanor, 1969), where alkaline phosphatase seems to be constitutive, whereas acid phosphatase is derepressed under conditions of phosphate starvation. However, in Neurospora crassa (Metzenberg \& Chia, 1979) the synthesis of both acid and alkaline phosphatase is controlied by a common regulatory system in which inorganic phosphate plays an important role.

The results presented here show that alkaline phosphatase synthesis in $C$. utilis depends on the presence of a fermentable carbon source such as glucose, fructose or mannose. No enzyme activity is found in cells growing in ethanol-containing medium. In contrast, the type of carbon source has no effect on the synthesis of either 'heavy' or 'light' acid phosphatase. 
A similar effect has been reported in the regulation of alkaline phosphatase synthesis in Bacillus licheniformis (Hydrean et al., 1977), which is derepressed during growth on glucose and glycerol and, to a much smaller extent, on lactate, pyruvate or succinate. However, in this micro-organism extracellular phosphate has a profound influence on alkaline phosphatase synthesis, although the authors demonstrated that enzyme repression or derepression is not related to the intracellular phosphate content of the cells.

Further work needs to be done before the regulatory role of carbohydrate metabolism in alkaline phosphatase synthesis in $C$. utilis can be explained. From our results, it is clear that acid and alkaline phosphatase synthesis are not regulated in the same way in the yeast strain studied.

\section{REFERENCES}

AMEs, B. N. (1966). Assay of inorganic phosphate and phosphatases. Methods in Enzymology 8, 115-118.

AsHWELL, G. (1957). Colorimetric analysis of sugars. Methods in Enzymology 3, 73-105.

Elorza, M. V., Rodriguez, L., Villanueva, J. R. \& SENTANDREU, R. (1978). Regulation of acid phosphatase synthesis in Saccharomyces cerevisiae. Biochimica et biophysica acta 521, 342-351.

Fernández, M. P., SuÁrez Rendueles, M. P. \& GASCóN, S. (1981a). Molecular forms of yeast acid phosphatase: cellular localization. Cellular and Molecular Biology 27, 113-118.

Fernández, M. P., Gascón, S. \& Schwencke, J. $(1981 b)$. Vacuolar alkaline phosphatase from yeast. Some enzymatic properties. Current Microbiology 6, 121-126.

Fernández, M. P., Suárez Rendueles, M. P. \& GASCÓN, S. (1982). Synthesis and regulation of molecular forms of yeast acid phosphatase. Cellular and Molecular Biology (in the Press).

Gascón, S. \& Lampen, J. O. (1968). Purification of the internal invertase of yeast. Journal of Biological Chemistry 244, 1567-1572.

Hydrean, C., Ghosh, A., Nallin, M. \& Ghosh, B. J. (1977). Interrelationship of carbohydrate metabolism and alkaline phosphatase synthesis in Bacillus licheniformis 794/c. Journal of Biological Chemistry 252, 6806-6812.

Kitazume, Y., YCAS, M. \& Vincent, W. S. (1962). Metabolic properties of a ribonucleic acid fraction in yeast. Proceedings of the National Academy of Sciences of the United States of America 48, 265-282.

Lehman, J. F. \& Metzenberg, R. L. (1976). Regulation of phosphate metabolism in Neurospora crassa: identification of the structural gene for repressible alkaline phosphatase. Genetics 84, 175182.

Littlewood, B. S., ChiA, W. \& Metzenberg, R. L. (1975). Genetic control of phosphate-metabolizing enzymes in Neurospora crassa: relationships among regulatory mutations. Genetics 79, 419-434.
Metzenberg, R. L. \& ChiA, W. (1979). Genetic control of phosphorus assimilation in Neurospora crassa: dose-dependent dominance and recessiveness in constitutive mutants. Genetics 93, 625-643.

Mitchison, J. M. \& CreanoR, J. (1969). Linear synthesis of sucrase and phosphatases during the cell cycle of Schizosaccharomyces pombe. Journal of Cell Science 5, 373-391.

Nelson, R. E., Lehman, J. F. \& Metzenberg, R. L. (1976). Regulation of phosphate metabolism in Neurospora crassa: identification of the structural gene for repressible acid phosphatase Genetics 84 , $183-192$.

Onishi, H. R., Tkacz, J. S. \& Lampen, J. O. (1979). Glycoprotein nature of yeast alkaline phosphatase. Formation of active enzyme in the presence of tunicamycin. Journal of Biological Chemistry 254, 11943-11952.

SchurR, A. \& YAGIL, E. (1971). Regulation and characterization of acid and alkaline phosphatase in yeast. Journal of General Microbiology 65, 291303.

SoMOGYI, M. (1952). Notes on sugar determination. Journal of Biological Chemistry 195, 19-23.

Toh-e, A., Ueda, S., Katimoto, S. \& Oshima, Y. (1973). Isolation and characterization of acid phosphatase mutants in Saccharomyces cerevisiae. Journal of Bacteriology 113, 727-728.

Tон-E, A., КАкімото, S. \& Oshima, Y. (1975). Genes coding for the structure of acid phosphatases in Saccharomyces cerevisiae. Molecular and General Genetics 143, 65-70.

Toh-E, A., Nakamura, H. \& Oshima, Y. (1976). A gene controlling the synthesis of non-specific alkaline phosphatase in Saccharomyces cerevisiae. Biochimica et biophysica acta 428, 182-192.

Tonino, G. J. M. \& STEYn-Parvé, E. P. (1963). Localization of some phosphatases in yeast. Biochimica et biophysica acta 67, 453-469. 